\title{
Harmonising insolvency law in the EU: New thoughts on old ideas in the wake of the COVID-19 pandemic
}

\author{
Emilie Ghio $^{1}$ | Gert-Jan Boon ${ }^{2}$ | David Ehmke ${ }^{3}$ | \\ Jennifer Gant $^{4}$ | Line Langkjaer ${ }^{5}$ | Eugenio Vaccari ${ }^{6}$
}

${ }^{1}$ Edinburgh Napier University, Edinburgh, UK

${ }^{2}$ Department of Company Law, Leiden Law School, Leiden, The Netherlands

${ }^{3}$ GT Restructuring, Berlin, Germany

${ }^{4}$ University of Derby, Derby, UK

${ }^{5}$ Department of Law, University of Aarhus, Aarhus, Denmark

${ }^{6}$ Department of Law and Criminology, Royal Holloway and Bedford Colleges, University of London, Egham, UK

\section{Correspondence}

Dr Emilie Ghio, Edinburgh Napier University, Edinburgh, UK.

Email: e.ghio@napier.ac.uk

Funding information

European Union

\begin{abstract}
While the harmonisation of insolvency law in the European Union (EU) has been a top priority on the European institutions' agenda in the last decade, it is well known that this endeavour has been slow and has often met resistance from the Member States. The COVID-19 pandemic revealed that top-down harmonisation of insolvency (i.e., introduced at EU level) has been temporarily halted. The urgency to control or mitigate the economically and financially destructive effects of the pandemic has, nevertheless, forced European governments to adopt domestic strategies and laws in the area of insolvency. Interestingly, however, such measures show that insolvency and restructuring law responses to the COVID-19 pandemic, albeit largely uncoordinated, reflect a phenomenon of bottom-up harmonisation (i.e., introduced by Member States) indicating a convergence towards common approaches. This paper interrogates the insolvency law responses to the COVID-19 pandemic in six European countries (Denmark, France, Germany, Italy, The Netherlands, the United Kingdom). It uncovers the inadequacy of the EU's harmonisation
\end{abstract}


language, and the limits of harmonisation strategies in insolvency and restructuring law. Finally, it promotes the formulation of a wider-encompassing definition of "legal harmonisation".

\section{1 | INTRODUCTION}

The COVID-19 crisis, which hit the world with full force in 2020, represents one of the greatest health and economic crises in recent history. The pandemic paralysed the world economy, forcing many countries around the globe to take emergency measures. Countries' emergency responses to the crisis uncovered a tension between the continuous phenomenon of global economic interdependence and the tendency for nation-state governance during the crisis. Although this dichotomy was quite acute in the European Union (EU) at the onset of the pandemic - reflected overall by Member States' preferences for national solutions over common multilateral solutions - governments eventually converged towards similar responses to the spread of the virus. These responses to the crisis included partial or total isolation of populations, travel bans, and the temporary closure of non-essential businesses.

This so-called phenomenon of "copycat coronavirus policies"1 was the result of regulatory emulation, which occurred spontaneously and with limited direct impetus from the EU. Our article investigates whether insolvency and restructuring laws, policies, and measures followed a similar pattern. The study focuses on six selected European countries: Denmark, France, Germany, Italy, The Netherlands, and the United Kingdom (UK). From a methodological perspective, our contribution relies on a case study approach. Building on the findings of this case study, our paper then draws more general conclusions on the process of harmonisation across the EU. ${ }^{2}$

The harmonisation of insolvency laws has been at the top of the European institutions' agenda over the last decade. EU initiatives have intensified and gained momentum in the aftermath of the Global Financial Crisis of the late 2000s. They crystallised with the adoption of the European Commission Recommendation on a New Approach to Business Failure and Insolvency in 2014 (ECR 2014), ${ }^{3}$ the European Insolvency Regulation Recast 2015 (EIRR 2015), ${ }^{4}$ and the Preventive Restructuring Directive 2019 (PRD 2019). ${ }^{5}$ The COVID-19 pandemic has revealed some of the limits of these EU's harmonisation efforts.

The findings of our case study reveal that governments have adopted strategies and laws to control or mitigate the economically and financially destructive effects of the pandemic at national level, with no preliminary coordination at European or international level. Our article shows that the countries' respective strategies fall within three categories:

i. making use of, and adjusting, existing and reliable procedures;

ii. introducing new restructuring mechanisms; and/or

iii. introducing non-insolvency solutions.

An analysis of such measures shows that insolvency and restructuring law responses to the COVID-19 pandemic, albeit largely uncoordinated by top-down regulation, reflect a phenomenon of harmonisation through convergence towards common approaches. 
We base our argument on the premise that the objective of harmonisation is increased legal similarity across the Member States of the EU, which is ultimately conducive of European integration. This increased legal similarity can happen via EU-driven initiatives, that is, top-down harmonisation, or via Member States-driven initiatives, that is, bottom-up harmonisation. In the latter case, the coming together of legal systems can occur through different mechanisms, specifically convergence, exhibited by the similarity in the state-centric solutions adopted by countries in the wake of the COVID-19 pandemic.

The article thus advocates for greater synergy between these processes. It promotes the formulation of a wider-encompassing definition of legal harmonisation, understood as a multilayered concept, encompassing bottom-up, as well as top-down phenomena, which all ultimately aim at increasing legal similarity across legal systems. We therefore suggest that the European institutions should be more mindful of their harmonisation strategies and of their harmonisation narrative, to better reflect the variety of processes falling within the scope of harmonisation. This article therefore uncovers the inadequacy of the EU's harmonisation language and the limits of harmonisation strategies in insolvency and restructuring law. Specifically, we show that the EU narrative does not match how legal harmonisation is occurring in practice. Over the years, the EU has been very much focused on classic harmonisation measures such as regulations and directives. However, harmonisation policies and measures have evolved in a softer and more nuanced way over the years.

This discussion is timely as the EU embarks on its next step towards achieving greater harmonisation of insolvency laws across the EU. ${ }^{6}$ However, this analysis on the scope and nature of legal harmonisation goes beyond the insolvency and restructuring field. The harmonisation patterns in insolvency law are, therefore, indicative of broader EU patterns.

In fact, this discussion around the meaning of harmonisation is particularly relevant at a time when in addition to the current health crisis brought abought by the COVID-19 pandemic, European integration seems to have lost some of its shine and the European Union is experiencing some integrational panic. ${ }^{7}$ The last decade or so has unfolded in a rather dramatic way for the European Union, its market, and citizens. In the words of Platsas:
"the word 'crisis' is not merely common; it is everywhere ... Nationalisms and pop- ulisms are on the rise ... The naivety of the late 1990s and the early 2000s has given its place to considerable scepticism ... In 2015, the EU has been hit by the worst immigration crisis it has encountered in its history [whilst] in 2016, the United Kingdom's electorate voted ... to withdraw from the EU, otherwise the leading example of harmonisation efforts in the world to date. And the question is: what has the legal harmonisation thesis done to thwart certain or all of the above? Or, even more provocatively, is this the right time for one to engage oneself with another legal harmonisation discussion?"8

It can be argued that underlying these various crises confronting the EU is in fact a problem very much intertwined with the matter of harmonisation. It is, therefore, exactly the right time to revisit the question of harmonisation. Indeed, legal harmonisation has been confronted with several obstacles over the years, such as the protection of national sovereignty and legal cultures, as well as an overall rise in Euroscepticism, prioritising state-centric solutions to common issues. Eurosceptic tensions, which culminated with "Brexit," are probably the clearest proof that the: 
"seductive appeal of harmonisation is today tarnished [and its] role is increasingly contested." 9

The EU institutions are thus under greater pressure to adapt to overcome these challenges and our article proposes recommendation for such adaptation. Jean Monnet famously wrote that:

"people only accept change when they are faced with necessity, and only recognize necessity when a crisis is upon them [...] Europe will be built through crises, and [will] be the sum of their solutions."10

The COVID-19 crisis and the findings of the case study provide an impetus to review how legal harmonisation takes place in the EU and what the legal harmonisation thesis has done to thwart the crisis. Ultimately, this article draws attention to two matters of contention. The first one is the lack of precise harmonisation language and terminology; the second one is the role of the Member States as co-drivers of the harmonisation process. This contribution debunks the idea that harmonisation measures are necessarily top-down, passed in Brussels, behind closed doors and imposed on the national level. Rather, it demonstrates that the EU is an arena of dialectic harmonisation.

The article is structured as follows. Section 2 provides the harmonisation background against which our study is based. It discusses the integration agenda of the EU institutions over the years and more specifically, how the harmonisation of insolvency law across the Union has supported such integration. Section 3 is dedicated to the case study which investigates how the insolvency and restructuring regimes of six European countries have dealt with the COVID-19 pandemic. For the purposes of this section, the law is stated as at May 31, 2021. Finally, Section 4 analyses the findings of the case study against the integration and harmonisation background discussed in Section 2. It focuses on the effectiveness of the harmonisation strategies and language adopted by the EU over the years to promote the dialectic nature of the EU.

\section{2 | HARMONISING EUROPEAN INSOLVENCY AND RESTRUCTURING LAWS: THE HARMONISATION NARRATIVE AND AGENDA TO DATE}

\subsection{The integration agenda in the EU}

European integration is, and ever has been, a controversial idea. Commentators have traditionally put forward competing views over what the EU integration process should entail. These competing views can be classified within two paradigms. The intergovernmental view places Member States' interests as paramount in importance, whereas the supranational view advocates the good of the Union as the primary objective of the EU. ${ }^{11}$ The former view tends to favour limited EU "interference" with the regulatory regimes of the Member States, while the latter favours increased influence and higher levels of control over law and policy.

Integration in the EU context refers to the coming together of policies, principles, and laws among the Member States in order to align more closely with one another. ${ }^{12}$ The objective of such integration is to achieve a more homogenous Union, while retaining and protecting the individual infrastructures and cultures of each Member State. ${ }^{13}$ Current EU policy favours an approach of "differentiated integration", which refers to the flexible accommodation of Member State policy and preference when approaching the implementation of EU policy and legislation. ${ }^{14}$ 
A key driver of European integration is the harmonisation of laws and policies among the Member States. Accordingly, the first objective of harmonisation under the Treaty on the European Union (TEU) and the Treaty on the Functioning of the European Union (TFEU) is the establishment and integration of the internal market. ${ }^{15}$ Such a market can only function effectively if competition is not distorted, and if free movement of production factors is not impeded by existing divergences between the national legal orders. ${ }^{16}$ The objective of harmonisation is thus to create a coherent system for all actors and to provide them with a level-playing field. The policy of differentiated integration, however, also impacts the extent to which harmonisation can be achieved given the need to accommodate the diverse policy preferences of 27 Member States in order to ensure a consensus on legislation that can be implemented and enforced.

\subsection{Harmonising insolvency law to support the integration agenda}

The most important harmonisation basis is art 114 of the TFEU, which allows the EU to regulate those elements of private law, which creates direct or indirect obstacles to trade in the internal market. One of the primary objectives of the European integration project has been the creation of the internal market:

"an area without internal frontiers in which the free movement of goods, persons, services and capital is ensured."17

This objective was defined as the removal of barriers to intracommunity trade and movement, in order to merge national markets into a single European domestic market. ${ }^{18}$ From the outset, the removal of these barriers has occurred by means of harmonisation measures, under the unquestioned assumption that the establishment and integration of the internal market was only possible through the creation of common substantive and procedural legal rules valid for all Member States. ${ }^{19}$

Insolvency matters have a strong Union dimension. As observed by Balz, one of the architects of what is now the EIRR 2015:

"[a] functioning bankruptcy system is essential to any economy that aspires to achieve the freedoms of establishment of business and the free flow of goods, services and capital, and to integrate national markets into a unitary internal market."20

This argument has been widely discussed in scholarly literature, ${ }^{21}$ European policies, and legislation. $^{22}$

This is not to say, however, that a functioning bankruptcy (rectius, insolvency) system can only be achieved through top-down harmonisation, as this seems to have been the implied assumption of the European legislator in the past decades. While top-down harmonisation may be advantageous to achieve full harmonisation, such actions also risk being time consuming, interfering with aspects of national sovereignty and legal cultures; therefore, making top-down harmonisation difficult to achieve from an EU institutional perspective. Insolvency and restructuring laws are entrenched in local legal systems, as evidenced in several areas. For instance, most insolvency laws attempt to balance competing objectives, such as protecting creditors' 
rights while safeguarding the interests of the debtor, shareholders, and customers. However, domestic insolvency regimes take different approaches to protect these stakeholders. This suggests the need to explore whether decentralised or regional solutions may provide an adequate and effective alternative to top-down harmonisation. These solutions can take different shapes but often stem from regulatory competition.

Regulatory competition is very much a reality in the area of insolvency and restructuring law, alongside the European push for further harmonisation. In fact, over the past decade, many Member States have reformed their national insolvency and restructuring laws not because they were obliged to do so by the EU, but to implement best practices existing in other jurisdictions. ${ }^{23}$ As mentioned by Paulus, there has been:

"an almost feverish hectic (sic) among most of the European states to outdo the others in amending their laws [...] Each one of these jurisdictions is striving for improvement; thereby, however, always keeping in mind the status of the competitors' laws and, thus, restricting the competition to a field which is located on a solid block of numerous commonalities and uniformity." 24

The merits of regulatory competition in the field of insolvency and restructuring law have been widely discussed in academic literature. ${ }^{25}$ It brings with it the principle of try and err, according to which competition among states can result in a steady race for the adoption of best possible solutions. ${ }^{26}$ One of the by-products of regulatory competition is forum shopping. While forum shopping has its inefficiencies, especially of uncertainty and strategic behaviour, ${ }^{27}$ it also incentivises lawmakers to constantly improve their national regime to attract forum shoppers and prevent debtors/creditors within their own country to forum shop. ${ }^{28}$ At the same time, negative effects for stakeholders that lack the means to actively pursue or influence insolvency competition, such as non-adjusting creditors in particular, cannot be overlooked.

As it is apparent, competition can only occur if top-down harmonisation has not carved a single restructuring solution applicable throughout the EU. If the level-playing field for economic activity is even across the EU, this may temporarily benefit businesses, which can easily predict the laws applicable to their case in any given Member State while depriving national lawmakers of their ability and incentive to craft innovative legal solutions. ${ }^{29}$ In this context, harmonisation is seen as a strait-jacket stifling legal reform and the improvement of substantive law. ${ }^{30}$ With that said, current approaches which embrace differentiation in the EU's harmonisation efforts rarely amount to the harmonisation strait-jacket; rather, legislation such as the PRD provide ample scope for a variety of implementations, which may well still result in at least some level of continued regulatory competition in this area.

Apart from competition, other justifications explain why legal similarity, be it the result of convergence or top-down rule-making, should not be taken at face value as the most advantageous approach. A restructuring regime does not function in a vacuum. Extra-legal conditions like the lending and ownership structure (e.g., dispersed or concentrated) need to be considered. Similarly, other areas of the law (e.g., corporate law) are typically adjusted to the insolvency and restructuring regime to function in concert. ${ }^{31}$ For this reason, legal transplants will not always function as well in practice as hoped for in theory. ${ }^{32}$

Top-down harmonisation has been preferred as a regulatory method by the EU in insolvency and restructuring law since the 1960s, and has been regularly championed by stakeholders, ${ }^{33}$ notwithstanding whether or not it has been achieved given the difficulties that beset harmonisation in this area of law. The EU has made clear its position against forum 
shopping, ${ }^{34}$ which has served as a driver toward further top-down harmonisation to reduce the divergences that might otherwise encourage parties to seek restructuring and insolvency procedures outside of their natural procedural home.

\subsection{Harmonising insolvency law: Rationale and early years}

In the early years of the European Community, efforts to harmonise insolvency laws matched the integrationist narrative. The rationale for harmonising insolvency laws rested on the link between the integration and smooth functioning of the internal market and the need for coordinated actions at the Community level. For example, as early as 1970, the Draft Convention on Bankruptcy, Winding Up, Arrangements, Compositions, and Similar Proceedings stated that:

"the effect of the common market must be precisely to bring about a radical change [...] The Member States of the European Economic Community have agreed to establish between themselves a genuine and vast internal market conforming to the rules of free competition. Every effort must therefore be made not only to eliminate obstacles to the functioning of this market, but also to promote its development." 35

Due to the sensitive and complex nature of insolvency law, it took over 40 years for the first cross-border instrument to come into existence, in the form of the European Insolvency Regulation 2000 (EIR 2000). ${ }^{36}$ Because of "widely differing substantive laws", the EIR 2000 acknowledged that it was not:

"practical to introduce insolvency proceedings with universal scope in the entire Community."37

As a result, the European Community opted for procedural harmonisation. The EIR 2000 was a private international law instrument, which dealt with issues of jurisdiction, applicable law, recognition, and enforcement of insolvency decisions, as well as coordination of cross-border insolvency proceedings. It designated the applicable law, that is, restructuring and insolvency procedures that were already in place in the Member States, and it ensured that they were recognised throughout the Community.

At the time the EIR 2000 was passed, liquidation was the usual, if not the only, option for distressed companies in many EU Member States. While this focus on liquidation was reflected in the EIR 2000, the EU promoted the modernisation of the Member States' insolvency laws, notably through the sharing of best practices from selected Member States as well as the United States, based on the Open Method of Coordination (OMC) approach. The OMC is an EU policymaking process introduced at the Lisbon European Council in 2000. Rather than a reliance on prescriptive legislation, the OMC is a mode of soft governance that aims to spread best practice and achieve convergence towards EU goals in those policy areas falling under partial or full competence of the Member States, which includes insolvency and restructuring law.

Following this European nudge in the early 2000s, the UK adopted the Enterprise Act 2002, Ireland implemented the Examinership procedure, and Finland, France, Slovakia, and Spain, to name just a few, also updated their rescue frameworks. The state of insolvency laws across the EU continued to show important disparities in substance, however. As a result, by the time the Global Financial Crisis of the late 2000s hit Europe, the rescue culture was still not fully 
adopted in all Member States, which explains why the EU had to move away from this soft mode of governance in its approach to adopting the ECR 2014 and eventually the PRD 2019. Although this soft mode of governance has been largely abandoned due to its lack of teeth, a good example being the 2014 Recommendation that failed to find its feet among the Member States, the EU's policy of differentiated integration continues to allow for flexible legislation that takes into account Member State differences while relying on mutual trust and cooperation to ensure that those differences do not impede progress toward further legislative alignment.

\section{4 | The growth of a political commitment to the harmonisation of insolvency: The EU Institutions' narrative}

Since the introduction of the EIR 2000, the EU has promoted harmonisation of restructuring and insolvency law, which has intensified with the Global Financial Crisis of the late 2000s. In 2012, the European Commission (Commission) - prompted by a Resolution of the European Parliament $^{38}$ - announced its step-by-step approach to improve European insolvency law and introduce a European business rescue culture. ${ }^{39}$ Alongside the modernisation of the EIR 2000, which took place with the adoption of the EIRR 2015, the Commission adopted the ECR 2014. The ECR 2014 was quickly strengthened into a binding legislative instrument, the PRD 2019. While this section provides a contextual background for the harmonisation initiatives in the field of insolvency and restructuring law, it focuses specifically on the harmonisation narrative and strategies relied on by the EU institutions over the years.

\subsection{1 | European insolvency regulation recast 2015}

The first step on the EU institutions' harmonisation agenda was a revision of the EIR 2000. Ideas for reforming the European Insolvency Regulation are as old as the text itself, since art 46 of the EIR 2000 tasked the Commission to present a report on the overall effectiveness and efficiency of the EIR 2000 by June 2012. While the Commission concluded that the EIR 2000 was generally operating successfully in facilitating cross-border insolvency proceedings within the EU, it uncovered several issues, notably relating to the scope of the Regulation, jurisdictional rules (COMI and forum shopping), publicity rules, and rules dealing with group insolvency under the EIR $2000{ }^{40}$

Similar to the EIR 2000, the EIRR 2015 is a conflict-of-law, choice-of-forum instrument, which deals with the private international law dimension of insolvency law. It confirmed the EIR 2000 position that the widely differing substantive laws of the Member States still prevented introduction of insolvency proceedings with a universal scope. ${ }^{41}$ However, the new focus to promote rescue over liquidation, was reflected, inter alia, in the extension of the scope of the EIRR 2015 to include pre-insolvency restructuring proceedings. ${ }^{42}$ Herewith, the EIRR 2015 dovetails with the overall objective of the ECR 2014 and PRD 2019.

\subsubsection{European Commission recommendation on a new approach to business failure 2014}

In 2012, as the EU was grappling with the devastating effects of the global economic crisis of the late 2000s, which saw an average of 200,000 firms going insolvent per year in the $E U,{ }^{43}$ the 
Commission highlighted the need to support a more business-friendly environment for debtors in financial distress. It launched ideas to harmonise some areas of such laws, which were ripe for substantive harmonisation. ${ }^{44}$ This was elaborated on in the ECR 2014. A key rationale for this new non-binding harmonisation initiative was the need to:

i. promote a rescue and recovery culture across the $E U^{45}$ and

ii. create a level-playing field of national insolvency laws, which would, in turn, lead to improved access to credit and foreign investment. ${ }^{46}$

With this paradigm shift in the scope of harmonisation came a strategy shift. The ECR 2014 was the first concrete attempt by an EU institution to achieve substantive harmonisation of insolvency and restructuring law. The Commission reiterated that national insolvency rules vary greatly; however, it now argued that such discrepancies must be harmonised as they hamper restructuring of viable business. Greater coherence was deemed necessary to increase efficiency of national frameworks, maximise value for all creditors, encourage cross-border investments and facilitate restructuring of groups of companies. ${ }^{47}$ Despite championing further harmonisation, not only did the Commission opt for a soft law instrument, it also opted for a minimum harmonisation approach. ${ }^{48}$ Additionally, the Commission decided to focus its efforts on a particular aspect of restructuring and insolvency law: preventive restructuring frameworks. ${ }^{49}$ The Commission considered that such area was the most promising one to entrench a rescue culture in all of the Member States. ${ }^{50}$ Due to the limited take up of the Recommendations and even cherry picking by Member States, ${ }^{51}$ the EU strengthened its initiative subsequently into a Directive.

\subsection{3 | The preventive restructuring directive 2019}

The Commission presented a Proposal for a Directive on Preventive Restructuring Frameworks in November 2016 (PRD Proposal 2016). ${ }^{52}$ The policy objectives behind the Proposal were the acknowledgement that well-functioning insolvency frameworks covering a wide range of measures are an essential part of a good business environment. The PRD's main objective is to reduce the most significant barriers to the free flow of capital stemming from differences in Member States' restructuring and insolvency frameworks, specifically by focusing on preventive restructuring frameworks, that is, pre-insolvency proceedings. ${ }^{53}$ The inclusion of efficient preventive restructuring mechanisms or pre-insolvency proceedings within Member State insolvency frameworks would support trade and investment, help create and preserve jobs, and help economies to absorb more easily economic shocks causing high levels of nonperforming loans and unemployment. ${ }^{54}$ Fundamentally, the PRD 2019 will likely satisfy its aim of enhancing the rescue culture in the EU by improving the mechanisms supporting insolvency prevention.

Secondly and similarly to the ECR 2014, the PRD 2019 sets common objectives in the form of minimum standards, thus trusting the Member States to achieve the objectives set out in the Directive without overly intruding into national law-making activities. As mentioned by the Commission:

"[the] objective was not to interfere with what works well, but to establish a common EU-wide framework to ensure effective restructuring, second chance and efficient procedures both at national and cross-border level." 55 
The PRD 2019, therefore, merely offers a menu, rather than a truly harmonised framework, based on the codification of best practices already in place in some of the Member States' preventive restructuring regimes. ${ }^{56}$ Even in its top-down harmonisation efforts, the EU's instrument reflects and accommodates Member State preferences.

The EU approach to harmonisation in the field of insolvency has changed dramatically over the years. While the initial objective to establish and integrate the internal market has remained at the heart of the EU institutions' initiatives, the way in which harmonisation has been pursued has evolved to adopt a more incremental approach. ${ }^{57}$ The history of the early EU initiatives shows that the EU institutions' ambition to adopt a binding instrument in the shape of a convention harmonising substantive aspects of insolvency law across all Member States was eventually replaced by a more pragmatic approach. When these original initiatives faced strong political resistance, the EU institutions realised that if they were to reach a consensus among the Member States, they would need to decrease the scope and ambition of their harmonisation initiatives. The COVID 19 pandemic has further highlighted the limitations and potentially unrealistic approach of the EU's harmonisation strategy, as will be discussed in detail in the next section.

\section{3 | CASE STUDY OF SELECTED APPROACHES TO BUSINESS FAILURE MEASURES DURING THE COVID-19 PANDEMIC}

The COVID-19 pandemic revealed some of the limits of the EU harmonisation strategies, focused as they have been on preventive restructuring. Given the sharp economic shock that caused immediate insolvencies of many businesses, there was no time or opportunity to have any recourse to prevention, even if such procedures were available at the time, given the PRD 2019 was still in its implementation phase. The necessary lethargy by which the EU institutions move also made it impossible to act efficiently as a supranational organisation during such a time of immediate crisis. It is therefore not surprising that Member States resorted to devising emergency solutions at domestic levels to tackle the sweeping effects of the crisis.

Existing instruments have not provided the Commission with the adequate powers to issue delegated or implementing acts ${ }^{58}$ in the context of a pandemic. ${ }^{59}$ Adoption of new legal acts by the EU legislator is typically time consuming, as is the case with treaties, regulations, directives, and decisions. Recommendations and opinions may be adopted more quickly, but they will not be binding on the Member States. As a consequence, the EU legislator had to leave the initiative for resolving the immediate effects of the crisis to national governments. ${ }^{60}$

It should, however, be noted that the EU was not completely absent in the management of the crisis. First, the Commission actively called upon Member States to ensure a coordinated response to COVID-19. Ensuring the stability of the internal market has remained a core concern of the EU during the pandemic. ${ }^{61}$ Secondly, the Commission committed itself to making funds available to mitigate the economic effects. ${ }^{62}$ Thirdly, the Commission noted that with the limited EU budget, the main fiscal responses would have to come from the Member States. ${ }^{63}$ As such, in the spring of 2020, the Commission issued a temporary Framework for State Aid Measures to support the economy during the COVID-19 outbreak. The temporary framework laid out the compatibility requirements and provided for a swift response from the Commission. ${ }^{64}$ Furthermore, the Council facilitated meetings where experiences and approaches were shared, 
and the Commission communicated the various measures that were implemented, including regarding restructuring and insolvency law. ${ }^{65}$

Nonetheless, following the outbreak of the COVID-19 pandemic in February/March 2020, countries resorted to domestic solutions to mitigate the economic effects and limit the economic shock. ${ }^{66}$ This section discusses the national insolvency and restructuring responses to the COVID-19 pandemic in six European jurisdictions: Denmark, France, Germany, Italy, the Netherlands, and the United Kingdom. By adopting this approach, findings are generalised, similarly:

"to the way a scientist generalises from experimental results to theory."67

Specifically, the different insolvency responses to the COVID-19 crisis in the selected countries are being assessed insofar as they can be informative about the harmonisation process among countries with strong judicial, political, and economic links. This includes measures implemented between March 2020 and March 2021. The survey reviews these measures from three legislative angles:

i. the extent to which existing restructuring and insolvency tools have been adjusted;

ii. the new restructuring and insolvency tools that have been introduced; and

iii. what non-insolvency solutions have been adopted to avoid insolvency?

\section{1 | Adjusting tried and tested measures}

In times of crisis, decisions need to be taken about allocation of limited resources. A common approach from legislatures and governments taken from commercial practice is to adopt a policy of retrenchment, thereby refraining from introducing sweeping changes to existing laws. ${ }^{68}$ Similar to companies that reduce "costs, assets, products, product lines, and overheads," 69 states that choose to retrench focus their resources on supporting key sectors of the economy. They refrain from introducing comprehensive reforms to their legal frameworks, at least during the immediate aftermaths of the crisis. It is, therefore, natural for governments and legislatures to fall back on and, where necessary, adjust tried and tested measures in times of crisis.

The rationale for following this strategy of adjusting tried and tested measures is rather uncontroversial. Changes require players to learn and adapt to the new rules. In the immediate moments after their introduction, tweaks in legislation are frequently needed to deal with problems arising from its implementation. Tried and tested rules are a "safe harbour" known to all players in the insolvency arena.

At the same time, no crisis should be wasted. Existing players are aware of the limits of their systems, as they have been played according to those rules for quite a long time. For most of the countries considered in this sample, the crisis has been an opportunity to tweak their rules, to make them more efficient and effective. In other words, many countries have followed the old saying "less is more" and while some countries have used the crisis as a reason to permanently reform their law, others have adjusted their regulatory frameworks only temporarily.

This "less is more" approach is evident in countries such as Denmark and Italy. In Denmark, earlier attempts to introduce significant changes to the Danish Bankruptcy Act failed to meet the needed support in the insolvency Community and, therefore, were never 
translated into legislative proposals. ${ }^{70}$ As a result, the Danish legislator has amended the existing restructuring procedure irrespective of the contingent issues raised by the COVID19 pandemic. Some of these changes can be described as mechanisms to make the insolvency system more efficient. This is, for instance, the case with the introduction of a fasttrack procedure for business transfers, which allows businesses to transfer their assets during the insolvency procedure without a meeting with formal voting. Another such example is making the appointment of additional professional experts in restructuring procedures voluntary, rather than mandatory. ${ }^{71}$

Other changes further promote rescue over liquidation solutions. These are, among others, the removal of the automatic conversion of a restructuring into liquidation for failure to approve a restructuring plan. In addition, recent reforms have also equalised the treatment of employees and workers in both liquidation and restructuring processes. ${ }^{72}$

Similar trends of tweaks to the law can be observed in Italy, despite the fact that its law has little in common with the Danish framework. While Italy is in the process of implementing a new Crisis and Insolvency Code, its entry into force has been postponed until September 1,2021 . Meanwhile, the legislator has adopted a series of significant changes to the existing system, in an effort to make it more efficient and rescue-oriented.

One of the most significant amendments in the area is the introduction of a revised statutory definition of "crisis", which occurred by means of Legislative Decree 147/2020. The existence of a situation of crisis is an eligibility requirement for the commencement of a formal insolvency or rescue proceeding. This definition changed from "a situation of economic and financial difficulty" to "a significant economic and financial imbalance". The effect of such an amendment is to make it more difficult to commence proceedings without the consent of the debtor, thus indirectly promoting negotiated and conciliatory solutions to overcome situations of financial distress.

Even in other countries, which are implementing sweeping reforms of their restructuring practice, these transformations are occurring against a background where existing measures are adapted to meet the new challenges raised by the COVID-19 pandemic. For example, in the Netherlands, although no amendments have been introduced to the insolvency test, courts and insolvency players have implemented novel practices and mechanisms to adapt to the changed market. ${ }^{73}$ These practical changes pursue a common goal: to limit the number of circumstances in which a creditor could file an insolvency petition. As a result, courts tend to adopt a more stringent approach on any applications for liquidation, and they will consider the impact of the COVID-19 pandemic in assessing pending petitions. ${ }^{74}$

Similar trends can be observed in other countries in this case study. In Germany, the obligation to file for insolvency, enforced with criminal sanctions, has been suspended for many debtors affected by the crisis. ${ }^{75}$ Directors' personal liability for payments made after the debtor has become insolvent has been substantially relaxed. The same applies for the liability of lenders who lend to distressed debtors and thus contribute to the delay of insolvency. Finally, claw-back rights have been scaled back to incentivise fresh capital inflow during the pandemic. ${ }^{76}$ All of the aforementioned adjustments are temporary to overcome the immediate effect of the pandemic.

Similarly, pursuant to French insolvency laws, debtors are generally required to file for bankruptcy within 45 days of cessation of payments. ${ }^{77}$ In recognition of the impending economic downturn caused by the COVID-19 pandemic, art 1 of the Ordinance of March 27, 2020 fixed the date of cessation of payments to March 12, 2020, for the period of the state health emergency (which was prolonged until August 23, 2020). ${ }^{78}$ Equally, in the United Kingdom, 
the Corporate Insolvency and Governance Act 2020 (CIGA 2020) temporarily banned winding up petitions based on statutory demands served between March 1, 2020 and March 31, 2021. It also restricted winding up petitions from being presented or winding up orders being made from April 27, 2020 to March 31, 2021 if a company cannot pay a debt for COVID-19-related reasons.

Furthermore, similar to Germany, the legislator in the United Kingdom intervened to suspend wrongful trading provisions under s214 of the Insolvency Act 1986 for actions taken prior to insolvency in relation to which the director knew or ought to have known that there was a reasonable prospect of the company avoiding insolvent liquidation but failed to take steps to minimise the potential losses to the company and its creditors. The suspension was in place for a look-back period beginning on March 1, 2020, ${ }^{79}$ initially taking effect retrospectively for 3 months from that date and ending on September 30, 2020. This has been extended on several occasions and, at the time of writing, applies to a look-back period beginning on April $30,2021 .^{80}$

\section{2 | Introducing new mechanisms}

It would be surprising if, however, such commonality of goals and approaches could be observed even when countries decide to introduce sweeping changes to their legal frameworks during a crisis. Nevertheless, our case study shows that remarkable convergence is also being observed with reference to those countries that have introduced new mechanisms in their restructuring frameworks, even if the discussion on the introduction of such mechanisms was already under way before the pandemic hit. As it will become apparent below, the pandemic accelerated and re-focused an ongoing debate.

For instance, on January 1, 2021, the Netherlands introduced the WHOA (Wet homologatie onderhands akkoord) in the Dutch Bankruptcy Act (Faillissementswet, DBA). The WHOA is a new, mainly out-of-court restructuring procedure available to companies in financial distress. Built on the basis of the Anglo-American tradition of schemes of arrangement and the Chapter 11 procedure, as well as the PRD 2019, the WHOA allows the debtor, but also creditors and shareholders, to propose a plan to restructure the debtor's financial obligations. ${ }^{81}$ Once approved by the relevant percentages in each class of creditors or shareholders (two-thirds in value), ${ }^{82}$ and subject to court confirmation, this plan becomes binding on all affected creditors and shareholders. ${ }^{83}$ Subject to certain safeguards, the WHOA can become binding not only on the dissenting creditors and shareholders in each class, but also on dissenting classes by means of a cross-class cram-down. ${ }^{84}$ Furthermore, the WHOA permits the court to terminate executory or onerous contracts on the debtor's request. ${ }^{85}$

The impossibility of binding dissenting classes of creditors has been one of the major reasons that has pushed the English legislator to fast-track and recently introduce a new restructuring proceeding through the CIGA 2020, located in Part 26A of the Companies Act 2006 and frequently referred to as the "Part 26A restructuring plan". The new Part 26A restructuring plan procedure is available to all companies encountering, or likely to encounter, financial difficulties that are affecting, or will or may affect, their ability to carry on business as a going concern. The new s901A(3) of the Companies Act 2006 requires, again as a threshold condition, that a "compromise or arrangement" must be proposed between the company and its creditors (or any class of them) or its members (or any class of them), and the purpose of the compromise or arrangement must be to: 
"eliminate, reduce or prevent, or mitigate the effect of any of the financial difficulties."

For the plan to be approved, it must receive the assent of $75 \%$ in value of each class of creditors. To further facilitate the approval of the plan, the new restructuring procedure features a crossclass cram-down. Similar to the WHOA, the cram-down mechanism allows dissenting classes of creditors to be bound by the plan, if sanctioned by the court as fair and equitable, and if the court is satisfied that those creditors would be no worse off than if the company entered an alternative insolvency procedure. As in the case of the WHOA, the new pt 26A restructuring plan allows the contracting parties to modify existing contracts.

Both the Dutch WHOA and the English Part 26A restructuring plan can be seen as attempts to translate into law (and practice) the recommendations enshrined in the PRD 2019. While the WHOA is an example of top-down implementation, the United Kingdom provides an interesting example of bottom-up convergence towards best practices. Although not bound to implement the Directive due to leaving the EU, the UK's CIGA 2020 entails several elements largely reflecting the provisions of the Directive, possibly to defend its position within the ongoing institutional competition with other European countries.

A similar trend can be observed in Germany, where a new framework for restructurings outside of formal insolvency proceedings was introduced. Under the new German restructuring law (StaRUG), ${ }^{86}$ debtors can restructure their financial obligations outside of formal insolvency proceedings, generally provided that the relevant debtor is not yet obliged to file for insolvency. The core element of this new toolset is the restructuring plan, which is prepared by the debtor and submitted to its creditors for approval. This plan can be used to compromise any form of debt as well as to modify equity and rights in collateral, including collateral provided by associated companies.

Additionally, individual provisions of contracts among multiple parties and with multiple parties at identical terms can be modified through the plan, that is, most importantly bond terms and inter-creditor agreements. ${ }^{87}$ If a $75 \%$ majority of the members in each group approves the proposed restructuring plan, the plan is adopted and will bind the dissenting stakeholders. Similar to the WHOA and the pt 26A plan, a cross-class cram-down is available under certain conditions. ${ }^{88}$ On the debtor's request, a stay of up to 8 months may be imposed so as to shield the procedure from disruption by individual enforcement or the liquidation of collateral. ${ }^{89}$

The StaRUG, thus, offers German corporate debtors a new restructuring tool for early restructurings, primarily for financial restructurings, as an alternative to the established German insolvency (plan) procedure, which has already been in place for many years. The German insolvency plan procedure effectively provides similar tools for a (cross-class) cram-down to bind creditors and shareholders to an insolvency plan. ${ }^{90}$ It also provides additional tools, such as a comparatively strong automatic stay ${ }^{91}$ and the right to choose performance or termination of executory contracts. ${ }^{92}$ However, the new StaRUG-restructuring procedure is still a novelty and an important addition for corporate debtors seeking to restructure their financial obligations. For the first time in Germany, debtors have a chance to restructure their debts outside of formal insolvency with a binding majority vote in a procedure that strictly guarantees the debtor's control of its business and the procedure.

Even if the introduction of these procedures as well as their content have been influenced by the EU harmonisation process, it would be wrong to claim that they are solely reactionary approaches to the PRD. They do represent comprehensive, much-needed answers to domestic calls for reform of the countries' domestic frameworks. This is especially the case for some of 
the countries considered here, such as the Netherlands, which before the enactment of WHOA had no effective restructuring law to bind dissenting creditors to a plan. The discussion around the ECR 2014 first and the PRD 2019 later may have also triggered a regulatory competition among the Member States to modernise their restructuring systems. The COVID-19 pandemic seems to have simply accelerated this process, as evidenced by the fact that, in the United Kingdom, consultations over the introduction of the pt $26 \mathrm{~A}$ restructuring plan date back to $2016 .^{93}$

In addition in the United Kingdom, the government has now published regulations aimed at pre-packaged sales to connected parties which occur by means of an administration proceeding. ${ }^{94}$ The term "pre-packaged sale" refers to an arrangement under which the sale of all or part of a company's business or assets is negotiated with a purchaser prior to the appointment of an administrator and the administrator effects the sale immediately on, or shortly after, appointment. ${ }^{95}$ Currently, pre-packaged sales are largely deregulated. Companies and practitioners need only to comply with professional guidelines known as Statement of Insolvency Practice 16 (SIP 16). At the moment, SIP 16 is not legally binding, even if failure to comply can result in regulatory or disciplinary action against the insolvency practitioner.

This state of affairs will change if the matter is regulated according to the legislative proposal of the draft regulations. In the proposal, if an administrator wishes to dispose of all or a substantial part of a company's assets within the first 8 weeks of the administration to one or more connected persons, then the administrator will need to obtain the creditors' approval or an independent written opinion by an "evaluator". This written opinion will be made available to the creditors and a copy will need to be filed at Companies House.

This legislative proposal aims to promote the timely and conscientious rather than abusive use of pre-packaged administration procedures. Similar trends can also be observed in Italy. With the enactment of a new comprehensive Crisis and Insolvency Code by means of Legislative Decree 38/2019 (as amended by Legislative Decree 147/2020), Italy has introduced new and reformed existing procedures with the purpose of promoting the timely and conscientious use of insolvency mechanisms. The new concordato preventivo shares significant commonalities with the revised English framework. In addition, one of these newly introduced mechanisms known as procedura d'allerta (alert procedure) draws some of its key elements from the French procédure d'alerte. ${ }^{96}$ The alert procedure, however, seems also to have been inspired by recent regulatory reforms in the United Kingdom, ${ }^{97}$ thus showing that on this same matter, Italy, France, and the United Kingdom are converging towards the use of common strategies to alleviate corporate distress.

A brief analysis of these regulatory trends suggests that European countries are moving towards the implementation of similar insolvency and restructuring provisions and mechanisms, focused on the facilitation of the rescue of distressed, yet viable, businesses, while especially promoting early restructurings and giving debtors a second chance to pursue such goal as a debtor in possession. Even in the absence of obligatory provisions such as those laid out by the PRD 2019, countries have been following a common path and learning from each other's experience, thus promoting a significant degree of bottom-up legal convergence. There may be several reasons for such a choice. One of the most prominent factors that may have contributed to such an outcome is that while nuanced differences can be explained by national interests and different legal (e.g., corporate, finance, insolvency laws) and extra-legal (e.g., structure of ownership and credit, lending practice) conditions per country, the lawmakers in every country have been forced to react to a global shock.

The COVID-19 pandemic has created a climate where business failure is not primarily associated with bad management. While the de-stigmatisation of insolvency and business failure in 
national legislations has been an ongoing objective of EU institutions, ${ }^{98}$ it was only "thanks to" the COVID-19 pandemic (and some mandatory recommendations in the PRD 2019) that member states finally acknowledged that failure may be primarily caused by external factors, rather than poor managerial decisions.

\section{3 | Non-insolvency law solutions}

Insolvency law measures are not, however, the only way to prevent or deal with financial distress. For instance, governments all over the world have adopted emergency packages to support their national economies. ${ }^{99}$ Many of these packages include tax reliefs, loans, direct investments and other non-insolvency and non-legal solutions.

In general, these non-insolvency solutions serve two purposes. The broader and more general purpose is to prevent a widespread financial collapse in society as a whole. A more specific purpose is to provide assistance to debtors, who are facing financial difficulties by reason of the crisis. In most countries these non-insolvency law measures have been amended, prolonged, and expanded several times during the pandemic to continuously provide adequate relief for financially distressed debtors. However, this may also result in fragmented and sometimes inconsistent approaches. ${ }^{100}$ This sub-section investigates the degree of convergence observed in the implementation of these non-insolvency changes among the countries considered in this case study.

It goes beyond the scope of this article to provide a detailed analysis of the measures adopted in each country considered in this case study. However, our study ${ }^{101}$ shows that, similarly to what has been observed in Sections 3.1 and 3.2 with reference to insolvency measures, most of the solutions implemented in the countries considered herein present significant degrees of commonality. Particularly, these measures can be classified within two overarching categories:

i. solutions and measures that provide liquidity in form of loans to businesses; and

ii. compensation schemes to cover for costs and losses of income.

While other non-insolvency legal measures, such as special protection for tenants to protect them from termination in case of delayed payment, could also be observed, loans, and compensation schemes are by far the most significant relief measures taken during the crisis.

In all six countries, the legislators have implemented liquidity-enhancing solutions for businesses hit by the COVID-19 pandemic. A common tool has been an easier and cheaper access to new finance. Some countries have issued state loans, such as the A-Tax and VAT-loans issued by the Danish State where a business can apply for an interest-free loan corresponding to the amount of income tax and VAT contributions which were reported on time. In all six countries, however, the State also provided various guaranties to lenders, who granted credit to distressed companies. A few examples should be mentioned here.

In Italy, the Cassa Depositi and Prestiti $\operatorname{SpA}$, a joint stock company controlled by the Government, supported the Italian banks to grant loans to business affected by the COVID-19 pandemic. In the United Kingdom, similar measures were adopted by means of the Coronavirus Large Business Interruption Loan Scheme and the Coronavirus Business Interruption Loan Scheme. ${ }^{102}$ In Germany, the state-owned development bank KfW rolled out massive lending programmes for subsidised loans (together with bank lenders) provided to businesses in trouble 
during the pandemic. Finally, another common measure to foster business liquidity has been deferral of certain tax and VAT payments, that is, basically a loan provided by the tax authorities. There has been a remarkable degree of convergence in the use of such measures across the countries considered in this case study.

States have not only provided liquidity for distressed businesses. They have also introduced a number of compensation schemes or subsidies. Contrary to loans, compensation is nonrefundable, at least for losses which are caused by officially enforced shutdowns. Therefore, compensation does not only give a short-term relief in form of liquidity, but also facilitates the re-balancing of the business' balance sheet. Examples of such compensation schemes are the different variations of furloughed schemes introduced in all six countries. In Italy, furloughed employees' wages are paid by a public fund financed through regular payments from employers' expenses ${ }^{103}$ and, in the United Kingdom, employers can apply for a grant to cover $80 \%$ of furloughed employees monthly wages, subject to a monthly cap. ${ }^{104}$ Similar schemes have been introduced in Denmark, ${ }^{105}$ the Netherlands, ${ }^{106}$ Germany $^{107}$, and France. ${ }^{108}$ The furlough schemes do not only serve the purpose of compensating losses and hereby preventing insolvency for the employers. They also and perhaps more importantly aim at reducing the impact of the COVID-19 pandemic on employment numbers.

This is not to say that all measures share common elements, as there are country-specific issues that have been addressed in uncoordinated ways, such as the nationalisation of the two Italian airline companies Alitalia and Air Italy, ${ }^{109}$ whereas Air France-KLM received (state guarantees on) loans from the French and Dutch governments. ${ }^{110}$ However, this cursory analysis of non-insolvency measures suggests once again that the countries considered in this case study have adopted similar initiatives, even in the absence of a top-down coordination from the EU.

\section{4 | Conclusions}

While the last decade has shown a strong commitment of the EU legislator to further harmonise selected aspects of restructuring and insolvency laws, specifically preventive restructuring, in the wake of the COVID-19 pandemic, Member States have seldom resorted to preventive restructuring mechanisms. This minimal recourse can be explained by the fact that preinsolvency proceedings are of no help to address the potential sudden rise in number of systemic insolvencies, caused by a pandemic. Pre-insolvency mechanisms focus on early warnings of financial distress and on instigating directors to take timely action to prevent insolvency. Therefore, the restructuring toolbox offered by the EU in the PRD was of limited use during the COVID-19 pandemic. $^{111}$

As the EU instruments which existed at the time COVID-19 hit (EIRR 2015 and PRD 2019) were of little use for companies, countries had to act swiftly and independently. This section investigated their reaction, with reference to tweaks to existing insolvency measures, the introduction of new instruments in the restructuring toolkit and the adoption of noninsolvency relief packages.

However, what our case study mainly reveals is the salient role of Member States during the crisis. In the absence of top-down harmonisation from the EU, national state-centric initiatives resulted in significant degrees of legal alignment and ultimately, a phenomenon of natural convergence. The role of Member States during the COVID-19 crisis has therefore not been incidental and Member States have been, in reality, drivers of the harmonisation and integration process. 


\title{
4 | ANALYSIS AND RECOMMENDATIONS
}

The findings of the case study are significant against the current harmonisation movement occurring in the EU, which has not been left without criticism. Bork has rightly pointed out that:

\begin{abstract}
"[h]armonisation is declared to be a necessary and meaningful instrument for improving the common market and this cannot be doubted. However, if harmonisation is part of the day-to-day work of the European Union, shouldn't there be an administrative department within the European Commission which supports harmonisation efforts on a more general level? None of this is apparent. The impression is that there is no theoretical framework for harmonisation at all [...]. A comprehensive theory of legal harmonisation has not yet been developed and it is still something to strive for [...] This is a lacuna which must be addressed before harmonisation of insolvency laws can be pursued in earnest.",112
\end{abstract}

We hope to contribute to the building of such comprehensive theory by focusing on the harmonisation narrative and strategies of the EU institutions. As mentioned above, the case study reveals that while the EU has been rather absent from the process of updating national legislation to tackle the COVID-19 crisis, Member States still contribute to the harmonisation movement.

Consequently, we argue that the harmonisation process needs to be revisited in light of these findings. In doing so, the EU institutions need to be mindful of their harmonisation language, as well as the harmonisation strategies used. Both should better reflect the regulatory phenomena which took place during the COVID-19 pandemic, in particular the process of natural convergence that has occurred amongst the Member States. We propose a new understanding of EU harmonisation, which should be less thought of as a mere top-down mechanism and rather, as a multi-layered approach to increase the similarity and compatibility of national legal systems.

\section{1 | Rethinking the language of harmonisation}

\subsection{1 | Semantics}

Before a comprehensive theory of harmonisation can be formulated, it is important to understand - and therefore define - what it is we are talking about. This first step is thorny already, because the word "harmonisation" has protean characteristics. Defining harmonisation is something that has proven profoundly elusive, even from the earliest days of scholarship on the topic. The word "harmonisation" is often used synonymously with other words, which is problematic. For example, the words "harmonisation" and "convergence" are used interchangeably to refer to the same process of coming together of national legal systems. ${ }^{113}$ On the other hand, "harmonisation" is sometimes opposed to the process of legal convergence, the former being a top-down process and the latter, a bottom-up mechanism.

The EU institutions are guilty of such imprecise terminology as well. The recent 2020 European Commission Inception Impact Assessment on "Enhancing the convergence of insolvency laws" is a prime example. ${ }^{114}$ First, while the word "convergence" is used in the title of the Commission's initiative, such concept is not defined anywhere in the document. Neither was it defined in the public consultation launched in November 2020 which accompanied the 
Inception Impact Assessment. Second, the Inception Impact Assessment also used the words "harmonisation" and "convergence" interchangeably. ${ }^{115}$

Our first recommendation, thus, concerns the language used by EU institutions. The European project is a complex machinery, whose functioning can be difficult to grasp for nonexpert and lay audiences. Undefined concepts lead to misconceptions, which in turn, exacerbate the communication gap between "Brussels" and its Member States. EU institutions should therefore be more cautious with semantics. Harmonisation and convergence have distinct meanings and if not clearly differentiated, the danger is to talk at cross purposes. This lack of methodology has been noted in the literature. ${ }^{116}$

An authoritative starting point is the literal meaning of these words, as found in the dictionary. "Harmonisation" is defined as:

"the act of making different people, plans, situations, etc. suitable for each other" "the act of making systems or laws similar in different companies, countries, etc. so that they can work together more easily."117

"Convergence" is defined as:

"[the] fact that two or more things, ideas, etc. become similar or come together"118

and, in evolutionary theory, as the:

"independent development of similar traits or features in unrelated species or lineages." 119

The definitions of the terms "harmonisation" and "convergence" reveal that both concepts aim at the coming together of legal systems, in a concerted effort aimed at increasing their similarity. However, while the result of both phenomena is the same, the processes are different.

We argue that EU institutions, policymakers as well as scholars, need to adopt a more precise language when discussing the regulatory phenomena occurring in insolvency and restructuring law. Harmonisation overall aims at increasing legal similarity. It can take two forms: if it moves from the supranational level to the domestic level, it should be referred to as top-down harmonisation; if it moves from the domestic level to the supranational level, it should be referred to as convergence.

\subsection{2 | The rhetoric of harmonisation}

Secondly, we recommend that the EU institutions be mindful of their harmonisation rhetoric. The wording adopted in various instruments has not always quite matched the content of these initiatives and this wording has been either disproportionate or seemingly contradictory at times, such as with the ECR 2014 and EIRR 2015, or too timid on other aspects, such as with the PRD 2016. Inconsistencies between language and regulatory content can be spotted firstly in the ECR 2014, which heralded itself as introducing a "new approach" to insolvency.

While it is acknowledged that some provisions within the Recommendation were somewhat new to some Member States, even some with mature insolvency systems, the overall rhetoric of the Recommendation was rather disproportionate and did not match the content of the Recommendation, which was merely a variation on a very familiar process, that is, Chapter 11 of the 
U.S. Bankruptcy Code and mainly laid down best practices in preventive restructuring already in place in several Member States. In any case, on the ECR 2014, Warner, for example, noted that the Commission's invitation that Member States align their laws:

"may have arrived a little late. Based on the 2014 INSOL report [...] most of the EU member states already had laws incorporating major features of rescue before the Recommendation was formally issued." 120

Another example of inconsistency in wording can be spotted in the EIRR 2015. Although the Commission used the word "recast" in its title, which is defined as "to change the form of something,"121 commentators have argued that the measure was "modest and unambitious"122 and that the rhetoric was:

"overblown and far divorced from the quite modest changes proposed in the revised Insolvency Regulation.",123

As stated by McCormack:

"[w]hile the modern tendency may be to hype everything and to herald eagerly rafts of new initiatives, this approach sows the seed of disillusionment and disappointed expectations."

On the other hand, the harmonisation discourse has also been, at times, too timid. While the EU institutions did in fact take into account national developments in the area, thereby codifying best practices into EU legislative instruments, it merely alluded to this codification approach, stating that:

"[t]he objective is not to interfere with what works well, but to establish a common EU-wide framework to ensure effective restructuring."125

In fact, besides the relative priority rule (art 11 of the PRD 2019), the PRD 2019 has not introduced any new concept or insolvency rule. Instead, the PRD 2019 has mostly relied on existing best practices in the area of preventive restructuring, such as the cram-down, moratorium and debtor in possession mechanisms, as well as protection for new money. ${ }^{126}$ Similarly, the EIRR 2015 did not significantly overhaul the status quo. For the best part, it codified practices, which had developed in the area of cross-border restructuring in previous years. For example, art 3 of the EIRR 2015 codified the jurisprudence of the CJEU around the concept of the COMI, ${ }^{127}$ as well as innovative practices devised by Member States. Articles 36 and 38 of the EIRR 2015 also codified the concept of "synthetic proceedings" created by British Courts. ${ }^{128}$

As Nelken has argued:

"[b]orrowing other peoples' law is seen as just a method of speeding up the process of finding legal solutions to similar problems - a process being encouraged all the more by the pressures towards convergence brought about by globalisation." 129

While this was stated explicitly in the European Commission Impact Assessment $2016,{ }^{130}$ it would be beneficial for the Commission to be clearer about its position. By clearly stating that 
the PRD 2019 was mostly codifying what already existed and what worked well, the Commission would most likely have encountered less resistance from the beginning of the negotiating process.

Overall, the EU institutions have not matched the wording in their harmonisation instrument to the reality of their efforts, which have mostly taken the shape of legal codification, rather than the introduction of novel ideas and concepts. As rightly pointed out by Warner:

\begin{abstract}
"it seems to me that this is the assumption behind the European Council Recommendation. It is not an invitation to be creative and design completely new rescue models. Instead, the Recommendation includes a list of traditional rescue tools and directs Member States to align their laws to those traditional rescue models."131
\end{abstract}

We therefore recommend that the EU institutions be more mindful of their harmonisation language and rhetoric, to better reflect the actual harmonisation methods adopted in practice which include initiatives at the Member States' level. We argue that such inclusive approach would support the case for further harmonisation across the EU which would most likely be better accepted by national governments. To accommodate diverse national policies and domestic interests, it is important that the EU acknowledge and give weight to natural convergence, stemming from the Member States' level. Rather than merely pushing for top-down harmonisation that has arguably so far failed to create a truly harmonised framework, recognising the more nuanced and multi-layered approach that allows for legal evolution and emulation within the EU could be the most promising path for future European law-making in this area. This would mean:

i. allowing Member States' some leeway in the formulation of their domestic insolvency and restructuring law policies;

ii. the sharing of best practices across Member States (possibly facilitated by the EU institutions); and

iii. the codification at the EU level of these provisions and mechanisms which have proven efficient and innovative.

\title{
4.2 | Rethinking harmonisation strategies and methods
}

This brings us to our second recommendation. Not only should the EU institutions be mindful about matching their harmonisation language to the efforts and initiatives undertaken to promote it; they should also reconsider their harmonisation strategy. Crises provide useful impetuses to rethink these strategies. The Global Financial Crisis of the late 2000s prompted the EU to introduce its "New Approach to Business Failure" policy, as well as to kick off its substantive harmonisation efforts. Similarly, our argument is that this crisis should not be wasted.

The COVID-19 crisis called into question the foundational and theoretical basis on which the EU institution have built their harmonisation efforts. Eidenmüller rightly observed that the harmonisation debates around the PRD had been "superficial" and:

"[paid] little attention to regulatory strategies and tools. [Were] the identified problems serious enough to do something, or should the status quo [have been] maintained? If action [were] take[n], should it be in the form of a Directive or by a 
Regulation? Should the chosen instrument contain options, and if so, for whom...? The Commission feebly attempt[ed] to answer all these questions in one sentence: "A binding instrument in the form of a Directive setting up minimum harmonised framework appears necessary to achieve the policy objectives on restructuring, insolvency and second chance.",132

Harmonisation is indeed a tool used by the EU institutions to integrate the internal market and ensure its smooth functioning. There is, therefore, a pressing need for academic and administrative support as well as a solid, overarching theory of harmonisation to develop in order to achieve this objective.

Our case study echoes Eidenmüller's comments and confirms this theoretical gap and misguided harmonisation strategy. Firstly, similarly to Eidenmüller's comment that the Commission has paid "little attention to regulatory strategies and tools", we note that no empirical studies or discussions have been conducted on the merit of top-down harmonisation, regulatory competition or state-centric solutions. All of these approaches can determine convergence of legal rules, which is ultimately in line with the EU institutions' objectives of increased integration of national legal systems. This lack of investigation into the merits of alternative regulatory approaches brings into question the purpose and legitimacy of the harmonisation process. The EU harmonisation initiatives appear:

"methodologically unsound and, in any case [...] clearly driven by the motive of supporting the Commission's preferred regulatory course [i.e. further harmonisation]."133

Secondly, we comment on the narrow harmonisation focus of the last decade focusing on preventive restructuring mechanisms. Although this focus is supported by valid reasons, ${ }^{134}$ we also acknowledge the political rationale behind this narrow harmonisation focus. Harmonising preventive restructuring frameworks is a "much safer political strategy" than:

"ventur[ing] into insolvency territory in a more narrow sense and embark[ing] on a harmonisation of Member States' corporate insolvency regimes.",135

This is noticeable from the Commission's explicit statement in the PRD 2019 that its aim was to:

"address [...] the most important problems which could be feasibly addressed by harmonisation.",136

However, this focus on preventive restructuring makes less sense from an economic perspective.

The economic rationale of this particular focus on preventive restructuring is highly questionable. This clearly emerged in the aftermath of the COVID-19 pandemic. While the Commission had explained that:

"[w]ell-functioning insolvency frameworks covering a wide range of measures are an essential part of a good business environment as it supports trade and investment, help create and preserve jobs, and help economies absorb economic shocks [...] more easily,",137 
The pandemic did in fact create an economic shock ${ }^{138}$ and existing EU restructuring and insolvency law instruments (EIRR 2015 and PRD 2019) were of little help to absorb such shock. While it must be noted that the PRD 2019 was not yet implemented in the Member States when the COVID-19 pandemic hit the EU, nor were the initial responses based on implementing the preventive restructuring toolbox. Indeed, the PRD 2019 would not have been a suitable instrument during the crisis as dogmatically, flattening the insolvency curve was no longer a matter of preventing insolvency.

These shortcomings were anticipated by experts who rightly predicted that the:

"Commission's proposal completely misses economic reality and the important filtering function that insolvency must fulfil: to restructure only viable firms and liquidate the non-viable ones." 139

Bork has stated that:

"[h]armonising insolvency law by avoiding insolvencies is a clear manifestation of the current 'restructuring hype' and it carries with it the danger of investing maximum energy into a solution that is only helpful in a minority of cases."140

He has also argued that:

"given that the EU strives for 'a higher degree of harmonisation in insolvency law,' it is quite remarkable that this process starts with harmonising the rules for solvent companies, i.e. for companies which are seeking to avoid looming insolvency."141

Tollenaar noted that, in the PRD Proposal 2016, the:

"Commission designed proceedings with a schizophrenic character that has fundamental architectural flaws" and that the "intent of the proposed directive is apparently to prevent the harmful effects that result from the inefficiencies of existing procedures. The solution should therefore be to remove the inefficiencies from existing insolvency procedures [...] not to prevent the opening of an insolvency procedure as such."142

Our case study supports the arguments made by these commentators. As a result, we propose to rethink the EU's harmonisation strategies. Legal harmonisation across the EU should be less thought of as the result of top-down practices and more as the result of concerted, multi-layered approaches aiming at strengthening the integration between separate national legal systems. The economic crisis triggered by COVID-19 pandemic showed the inadequacy of top-down harmonisation mechanisms as the only way to promote integration between Member States. As both top-down and bottom-up processes fall within the broader umbrella term of "harmonisation," and as both processes have their own advantages, there is a strong argument to rethink the harmonisation language at the European level.

We acknowledge that our discussion appears to reinforce the OMC approach originally adopted by the EU in the area of insolvency law over two decades ago. As discussed in Section 2, the EU originally studied examples of best practice and approaches by other States around the globe, in particular the United States, which was in effect a sort of bottom-up approach to 
policy-making. However, it was more of a bottom-up approach to the study of insolvency law rather than the bottom-up approach to the harmonisation law-making process we are advocating. Indeed, while the EU attempted to nudge Member States towards modernising their regimes, no EU harmonisation measure came out of the OMC method at the time.

This is where the title of this article takes on its full meaning: new thoughts on old ideas as our argument differs in the sense that we are arguing that the EU must acknowledge the role played by existing domestic rules and practices in the top-down harmonisation process, for its own sake, as it will result in decreased resistance to the EU measure. The EU should be mindful of the biases of Member States when adopting expressions such as "new approach" in the title of their harmonisation initiative and rather highlight in the harmonisation and text that the measure is in reality codifying existing practices.

While the EU's policy of differentiated integration allows for the flexibility and accommodation of Member State differences in its legislative approach, the downside of this is that it also provides space for obstinacy and objection where legislative activities are perceived as going to too far too fast. The PRD proposal, for example, acknowledges this fine line as the Commission stated that the "objective [was] not to interfere with what works well,"143 while the PRD also obviously introduces something that is new to many EU insolvency and restructuring frameworks. Language is key and there is ample room for improvement by the European institutions.

\section{5 | CONCLUSION}

The significance of EU legal harmonisation cannot be overstated, especially in the field of insolvency. Member States tend to be quite protective of their national sovereignty over the regulation of sensitive policy areas, such as insolvency, which is ultimately mirrored in corporate and investment decisions. Nevertheless, acknowledging the potential for insolvency laws to impinge on economic, social, and political issues of national interest, Member States have realised the need for consensual decision-making, and the harmonisation of insolvency laws in the EU is indeed happening. While these European harmonisation efforts need to be praised for their accomplishment against a complex and fragmented political environment, the EU institutions should accept the reality of the legal harmonisation process, which, in line with the Member States' expectations and practices, reflects a dual approach to increasing legal similarity across the EU.

Our case study reveals that, as the COVID-19 pandemic created similar problems in every country, governmental reactions shared common patterns. This has resulted in a phenomenon of natural bottom-up, legal convergence in an area that had previously been deemed too politically sensitive to engage in full substantive harmonisation. While we acknowledge that further research is needed to determine whether the regulatory phenomenon uncovered in our case study is coincidental or local, the findings are nonetheless significant in several ways.

First, this discussion is important as scholars have already warned that until we can rely on a more structured debate and a solid overarching theory of harmonisation, legal integration is unlikely to succeed. ${ }^{144}$ Our proposed understanding of the harmonisation process would also be attuned to the linguistics of the EU, which have long used the words "harmonisation" and "convergence" interchangeably in their policy and legislative documents. While it is argued that these processes should not be opposed, we suggest ways of better co-ordinating these strategies. Just as harmonisation measures can be driven by the EU institutions, they can also result from the elevation of best practices and bottom-up national solutions. 
Secondly, while the Commission embarks on a new harmonisation initiative in the field of insolvency and restructuring law, ${ }^{145}$ the EU is still battling Eurosceptic tensions and legitimacy challenges. This discussion around the phenomena encompassed within the scope of harmonisation and the role of Member States in the harmonisation processes is thus particularly important. The phenomenon of legal alignment and emulation which we noted in the area of insolvency and restructuring law amongst the countries studied in this article was not driven by top-down EU initiatives and rather, started at the bottom level.

The harmonisation process as applied to the field of insolvency law is instructive as an example for broader discussions at EU level around its overall harmonisation policy. We hope that by uncovering the role of Member States as drivers of European harmonisation, we can contribute to the demystification that EU laws are not merely passed in Brussels, behind closed doors, but that rather, the EU is an arena of dialectic harmonisation.

\section{ENDNOTES}

${ }^{1}$ Ivan Krastev, 'Copycat Coronavirus Policies Will Soon Come To An End' Financial Times (April 7, 2020) (August 19, 2021), available at: <https://www.ft.com/content/bd12b3ca-77e9-11ea-bd25-7fd923850377>.

${ }^{2}$ While we acknowledge that the United Kingdom is not a Member State of the EU anymore, the Brexit transition period was ongoing at the time the COVID-19 pandemic hit. For practical purposes of this study, the United Kingdom is assimilated to an EU Member State. However, despite the fact that it is likely that the United Kingdom and the EU will retain strong economic, financial, and regulatory ties post-Brexit, the conclusions of this study on the evolution of the harmonisation process within the EU are not directly applicable to the United Kingdom. However, if convergence happens absent top-down regulation, this provides a strong argument in favour of such phenomenon across the EU and possibly also involving the United Kingdom.

${ }^{3}$ Commission Recommendation C(2014) 1500 final of March 12, 2014 on a new approach to business failure and insolvency [2014] OJ L 74/65.

${ }^{4}$ Council Regulation (EU) 2015/848 of the European Parliament and of the Council of May 20, 2015 on insolvency proceedings (recast) [2015] OJ L 141/19.

${ }^{5}$ Directive 2019/1023 of the European Parliament and of the Council of June 20, 2019 on preventive restructuring frameworks, on discharge of debt and disqualifications, and on measures to increase the efficiency of procedures concerning restructuring, insolvency and discharge of debt, and amending Directive 2017/1132 (Preventive Restructuring Directive) [2019] OJ L 172/18.

${ }^{6}$ See European Commission, Inception Impact Assessment, "Enhancing the convergence of insolvency laws" (DG JUST A1, 11 November 2020).

${ }^{7}$ Mai'a Davis Cross and Xinru Ma, 'EU Crises and Integrational Panic: the Role of the Media' [2015] 22(8) J Eur Public Policy 1053.

${ }^{8}$ Antonios Platsas, ‘The Harmonisation of National Legal Systems. Strategic Models and Factors' (Edward Elgar 2017), vii.

${ }^{9}$ Stephen Weatherill, 'Why Harmonise?', in Takis Tridimas and Paolisa Nebbia (eds), EU Law for the TwentyFirst Century: Rethinking the New Legal Order (Hart Publishing 2004), 31.

${ }^{10}$ Jean Monnet, 'Memoirs' (Doubleday 1978), 109, 417.

${ }^{11}$ Paul Craig and Gráinne de Burca, 'EU Law: Text Cases and Materials' (OUP 2015), 6.

12 See Articles 3-4, Treaty on European Union OJ C 326/13 (TEU).

13 ibid.

${ }^{14}$ For EU policy on "differentiated integration", see Pascal Durand, Report on Differentiated Integration (2018/2093(INI)) (Committee on Constitutional Affairs 2019) A8-0402/2018 [2018]. For additional commentary, See. for example, Alkun Kölliker, 'Bringing Together or Driving Apart the Union? Towards a Theory of Differentiated Integration' [2001] 24 West Eur Polit 125; Claus Dieter Ehlermann, 'Differentiation, Flexibility, Closer Co-Operation: The New Provisions of the Amsterdam Treaty’ [1998] 4(3) Eur Law J 246. 
${ }^{15}$ Art 26(1), Treaty on the Functioning of the European Union OJ C 326/47 (TFEU).

16 See art 3 and Protocol 27, TEU.

17 Art 26(2), TFEU.

${ }^{18}$ Case C-41/93 France v Commission [1994] ECR I-1829, [19].

19 See, for example, Emanuela Carbonara and Francesco Parisi, 'The Paradox of Legal Harmonization' [2007] 132 Public Choice 367.

${ }^{20}$ Manfred Balz, 'The European Convention on Insolvency Proceedings' [1996] 70 Amer Bankruptcy Law J 485.

${ }^{21}$ See, for example, Bob Wessels, 'On the Future of European Insolvency Law' (INSOL Europe Academic Forum's 5th Edwin Coe Lecture 2012), 14: "My point of view is that in this concept of 'internal market', the creation of a European community and the further establishment of the European Union, including its four freedoms, strongly fostering and enhancing trade, business and investments across national boundaries, cannot (sic) be regarded as complete without a transparent and solid insolvency system."

22 See, for example, art 1, ECR 2014: "The objective of this Recommendation is to encourage Member States to put in place a framework that enables the efficient restructuring of viable enterprises in financial difficulty ... and contributing to reducing the obstacles to the smooth functioning of the internal market."; Recital 2, Council Regulation (EC) No 1346/2000 of May 29, 2000 on insolvency proceedings (EIR 2000): "The proper functioning of the internal market requires that cross-border insolvency proceedings should operate efficiently and effectively."

${ }^{23}$ For an overview of insolvency law reforms, see The World Bank Doing Business, 'Business Reforms in Resolving Insolvency' (August 19, 2021), available at: <https://www.doingbusiness.org/en/reforms/overview/topic/ resolving-insolvency>.

24 Christoph Paulus, 'A Vision of the European Insolvency Law' [2008] 17 Norton J Bankruptcy Law Pract 607.

${ }^{25}$ See. for example, Horst Eidenmüller, 'Abuse of Law in the Context of European Insolvency Law' [2009] 6 Eur Comp Financ Law Rev 1; John Armour, 'Who Should Make Corporate Law: EC Legislation versus Regulatory Competition' European Corporate Governance Institute, Law Working Paper 54/2005. For general discussions on the phenomenon of regulatory competition in the EU, see, for example, Hanne Birkmose, 'Regulatory Competition and the European Harmonisation Process' [2006] 17 Eur Bus Law 1075; Simon Deakin, 'Legal Diversity and Regulatory Competition: Which model for Europe?' [2006] 12(4) Eur Law J 440; Simon Deakin, 'Is Regulatory Competition the Future for European Integration?' [2006] 13(1) Swedish Econ Policy Rev 71.

${ }^{26}$ See generally Daniel Esty and Damien Geradin (eds), Regulatory Competition and Economic Integration: Comparative Perspectives (OUP 2001); Frank Easterbrook and Daniel Fischel, 'The Economic Structure of Corporate Law' (Harvard University Press 1996); Klaus Heine and Wolfgang Kerber, "European Corporate Laws, Regulatory Competition and Path Dependence” [2002] 13 Eur J Law Econ 47.

27 See. for example, European Parliament Directorate General for Internal Policies, 'Harmonisation of Insolvency Law at EU Level' (European Parliament 2010) (INSOL Europe Report), (August 19, 2021), available at: <http://www.eesc.europa.eu/sites/default/files/resources/docs/ipol-juri_nt2010419633_en.pdf>.

${ }^{28}$ Gerard McCormack, 'Bankruptcy Forum Shopping: The UK and US as Venues of Choice for Foreign Companies’ [2014] 63 Int Comp Law Q 815.

${ }^{29}$ David Ehmke, Bond Debt Governance (Nomos 2018) 36.

${ }^{30}$ A point made by Arthur Rossett, 'Unification, Harmonisation, Restatement, Codification, and Reform in International Commercial Law’ [1992] 40(3) Am J Comp Law 683, 688.

${ }^{31}$ See David Skeel, 'An Evolutionary Theory of Corporate Law and Corporate Bankruptcy' [1998] 51 Vanderbilt Law Rev 439. See also Ehmke (ibid 29), 32.

32 See Daniel Berkowitz et al., 'The Transplant Effect' [2003] 51(1) Am J Comp Law 163.

33 INSOL Europe Report (ibid 27). See also the position held by many stakeholders in the public consultation in 2016 ahead of the Proposal for an Insolvency Directive, which considered that substantive harmonisation of core elements of insolvency law would be useful: Consultation for an Effective Insolvency Framework within the 
$E U$ (European Commission 2016), available at: <https://ec.europa.eu/newsroom/just/item-detail.cfm?item_id= 30544>.

${ }^{34}$ See. for example, Recital 4, EIR 2000; Recitals 5 and 29, EIRR 2015.

${ }^{35}$ See EEC Draft Convention on Bankruptcy, Winding-Up, Arrangements, Compositions, and Similar Proceedings (1970), 49.

${ }^{36}$ EIR 2000. For a reference to the integration narrative in the text, see particularly Recitals 1, 2 and 3, EIR 2000. For a detailed account of the history behind the text, see Paul Omar, 'Genesis of the European Initiative in Insolvency Law' [2003] 12 Int Insolv Rev 147.

${ }^{37}$ Recital 11, EIR 2000.

${ }^{38}$ European Parliament resolution of November 15, 2011 with recommendations to the Commission on insolvency proceedings in the context of EU company law (2011/2006(INI)).

${ }^{39}$ Communication $\operatorname{COM}(2012) 742$ final from the Commission to the European Parliament, the Council, and the European Economic and Social Committee on a new European approach to business failure and insolvency [2012] OJ C 271/55 (Communication 2012), 1 and 5. On the EU institution's efforts in this regard, see further Gert-Jan Boon and Stephan Madaus, 'Toward a European Business Rescue Culture', in Jan Adriaanse and Jean-Pierre van der Rest (eds), Turnaround Management and Bankruptcy: A Research Companion (Routledge 2017), 238.

${ }^{40}$ Report from the Commission to the European Parliament, the Council and the European Economic and Social Committee $\operatorname{COM}(2012) 742$ final on the application of Council Regulation (EC) No 1346/2000 of May 29, 2000 on insolvency proceedings [2012] 10. This Report was based particularly on a study by Burkhard Hess, Paul Oberhammer and Thomas Pfeiffer, European Insolvency Law, The Heidelberg-Luxemburg-Vienna Report on the Application of Regulation (EC) No 1346/2000/EC on Insolvency Proceedings (External Evaluation JUST/2011/JCIV/PR/0049/A4) 2014.

${ }^{41}$ Recital 22, EIRR 2015.

42 ibid, art 1.

${ }^{43}$ Communication 2012 (ibid 39), 2.

44 ibid, 2-4. These areas included: (i) second chance for entrepreneurs; (ii) discharge periods; (iii) criteria for opening restructuring proceedings; (iv) ability of creditors to file for insolvency proceedings; (v) filing and verification of claims; (vi) restructuring plans; and (vii) second chances for SMEs.

${ }^{45}$ Recital 1, ECR 2014.

${ }^{46}$ ibid, Recitals 4, 8 and 11.

47 ibid, Recitals $2-4,8,11$.

48 ibid, Article 1(3).

${ }^{49}$ For a critical discussion of this narrow focus, see below at s4.2.

${ }^{50}$ See Gert-Jan Boon, 'Harmonising European Insolvency Law: The Emerging Role of Stakeholders' [2018] 27(2) Int Insolv Rev 150, analysing the appetite of the various stakeholders for the harmonisation process and finding reluctance with Member States and Ministries of Finance.

${ }^{51}$ European Commission, Directorate-General Justice \& Consumers of the European Commission, Evaluation of the implementation of the ECR 2014, 2 and 5. See also European Commission, Directorate-General Justice (A1), 2016/JUST/025 - Insolvency II, Inception Impact Assessment (3 March 2016), 7.

52 Proposal COM(2016) 723 final - 2016/0359 (COD) for a Directive of the European Parliament and of the Council on preventive restructuring frameworks, second chance and measures to increase the efficiency of restructuring, insolvency and discharge procedures and amending Directive 2012/30/EU [2016] Document 52016PC0723 (PRD Proposal 2016), 2.

${ }^{53}$ Recital 1, PRD 2019. See also PRD Proposal 2016, 5.

54 PRD Proposal 2016, 2.

${ }^{55}$ PRD Proposal 2016, 7. See also Recitals 12, 16 and 24, PRD 2019. 
56 David Ehmke et al., 'The European Union Preventive Restructuring Framework: A Hole in One?' [2019] 28(2) Int Insolv Rev 184.

57 Emilie Ghio, 'The EU Incremental Approach to Cross-Border Insolvency Regulation: a Critical Analysis' [2017] 28 Int Company Commer Law Rev 369.

58 For instance, the PRD 2019 provides for implementing powers and adoption of implementing acts for the Commission only regarding a data communication form: Recital 97, arts 29(7) and 30, PRD 2019.

${ }^{59}$ Criticisms about government responses to the COVID-19 crisis in the area of insolvency law are not limited to the EU. See. for example, in the U.S. context: Anthony Casey, 'Bankruptcy \& Bailouts; Subsidies \& Stimulus: The Government Toolset for Responding to Market Distress' [2021] Univ Chicago Legal Forum (forthcoming), available at: <https://papers.ssrn.com/sol3/papers.cfm?abstract_id=3783422>: "The choice of tools in the current crisis has been suboptimal. The government has yet to fully address the systemic economic challenges posed by COVID-19. The appropriate response requires further economic stimulus for small businesses rather than bankruptcy reform. The economic hardship is real and growing, and while the day of reckoning likely will not arrive as a wave of Chapter 11 bankruptcy filings, it will materialize in some form in the absence of appropriate systemic economic relief." See also Diane Dick, 'Bankruptcy, Bailout, or Bust: Early Corporate Responses to the Business and Financial Challenges of COVID-19' [2020] 40(1) Bankruptcy Law Lett 1 (August 19, 2021), available at: <https://papers.ssrn.com/sol3/papers.cfm?abstract_id=3765553>.

${ }^{60}$ While we note that art 107(1), TFEU, prohibits aid granted by a Member State which distorts or threatens to distort competition by favouring certain undertakings or the production of certain goods, Such aid is, however, compatible with the internal market if it helps to make good the damage caused by natural disasters or exceptional occurrences, or if it is to promote the execution of an important project of common European interest or to remedy a serious disturbance in the economy of a Member State.

${ }^{61}$ Communication from the Commission to the European Parliament, the European Council, the Council, the European Central Bank, the European Investment Bank and the Eurogroup COM(2020) 112 final on a Coordinated economic response to the COVID-19 Outbreak [2020].

${ }^{62}$ Communication from the Commission to the European Parliament, the European Council, the European Economic and Social Committee and the Committee of the Regions COM(2020) 143 final on the Coronavirus Response, Using every available euro in every way possible to protect lives and livelihoods [2020].

${ }^{63} \operatorname{COM}(2020) 112$ final 5.

${ }^{64}$ Communication from the Commission COM(2020) 1863 final Temporary Framework for State aid measures to support the economy in the current COVID-19 outbreak [2020] OJ C 91I/1. The Framework has been extended several times and is currently in place up until December 31, 2021. Up until this date, the five Member States covered in this case study have been granted approval by the Commission in 105 state aid scheme applications through the temporary framework, See. for an overview: "State Aid Actions" (European Commission 2020) (August 19, 2021), available at: <https://ec.europa.eu/info/live-work-travel-eu/coronavirusresponse/jobs-and-economy-during-coronavirus-pandemic/state-aid-cases_en $>$.

${ }^{65}$ See. for example, 'Policy Measures Taken against the Spread and Impact of the Coronavirus' (European Commission Directorate General Economic and Financial Affairs 2020), available at: <https://ec.europa.eu/ info/sites/info/files/policy_measures_taken_against_the_spread_and_impact_of_the_coronavirus_14042020. pdf $>$; Comparative Table of Insolvency Related Measures Adopted or Planned for Adoption in Member States (European Commission, Directorate-General Justice and Consumers 2020) (August 19, 2021), available at: <https://e-justice.europa.eu/fileDownload.do?id=8c19af5d-3e73-4de9-994b-0b975101b5eb >.

66 They were also called upon to take such actions, See, for example 'CERIL Executive Statement 2020-1 on COVID-19 and Insolvency Legislation' (CERIL 2020) (August 19, 2021), available at: <www.ceril.eu/news/ ceril-statement-2020-1>.

${ }^{67}$ Lee Ruddin, 'You Can Generalize Stupid! Social Scientists, Bent Flyvberg, and Case Study Methodology' [2006] 12 Qual Inq 797, 803.

${ }^{68}$ Keith Robbins and John Pearce, 'Turnaround: Retrenchment and Recovery' [1992] 13(4) Strateg Manage J 287; John Pearce and Keith Robbins, 'Retrenchment Remains the Foundation of Business Turnaround' [1994] 15(5) Strateg Manage J 417. 
69 John Pearce and Keith Robbins, 'Toward Improved Theory and Research on Business Turnaround' [1993] 19(3) J Bus Turnaround 613.

${ }^{70}$ Forslag til lov om andring af konkursloven, lov om Lønmodtagernes Garantifond, og lov om lønmodtageres retsstilling under insolvensbehandling ved virksomhedsoverdragelse, FT 2020-21, tillæg A, sp xx. See Betonkning 1555/2015 om Ansattes retsstilling under insolvensbehandling for the previous legislative proposals.

${ }^{71}$ L65, s1, nr. 4, 6 and 13, s1, nr. 14, 15, 17 and 27.

${ }^{72}$ L65 s1, nr. 8, 19, 21 and 22, s3, nr. 1.

73 This also applies to other countries, for the player's adaptability to changes in the market. See Sarah Paterson, 'The Adaptive Capacity of Markets and Convergence in Law: UK High Yield Issuers, US Investors and Insolvency Law' [2015] 78(3) Modern Law Rev 431.

${ }^{74}$ Rechtspraak, Tijdelijke afwijkende regeling Insolventiezaken rechtbanken vanwege bijzondere omstandigheden door de coronacrisis (TARIC) (version as at June 26, 2020, in force since March 26, 2020), available at: <https://www.rechtspraak.nl/SiteCollectionDocuments/tijdelijke-regeling-Insolventies-rechtbanken.pdf>.

${ }^{75}$ Until September 30, 2020, the suspension of the obligation to file for insolvency first applied to debtors unable to pay their debts, the statistically most important reason for filing for insolvency in Germany. After subsequent modifications of the respective law (COVInsAG), the exception applied to over-indebted debtors and eventually debtors also eligible for COVID-19 state aid, but no longer just to debtors unable to pay their debts.

${ }^{76}$ See Gesetz zur vorübergehenden Aussetzung der Insolvenzantragspflicht und zur Begrenzung der Organhaftung bei einer die COVID-19-Pandemie bedingten Insolvenz (COVID-19-Insolvenzaussetzungsgesetz/COVInsAG).

77 Arts L611-4, L628-1, L631-4 and L640-4, Code de commerce. For a definition of the concept of "cessation de paiements", see art L631-1, Code de commerce.

78 Ordonnance n 2020-341 du 27 mars 2020 portant adaptation des règles relatives aux difficultés des entreprises et des exploitations agricoles à l'urgence sanitaire et modifiant certaines dispositions de procédure pénale.

79 Schedule 14, Corporate Insolvency and Governance Act 2020, as amended by Rules 2 and 3, Corporate Insolvency and Governance Act 2020 (Coronavirus) (Suspension of Liability for Wrongful Trading and Extension of the Relevant Period) Regulations 2020 (UK) (SI 2020/1349).

${ }^{80}$ Catherine Noble, 'Temporary measures under the Corporate Insolvency and Governance Act 2020 (CIGA) \& the Suspension of Liability for Wrongful Trading Revisited' (Mills \& Reeve 2020) (August 19, 2021), available at: $<$ https://www.mills-reeve.com/insights/publications/temporary-measures-under-the-corporate-insolvency>.

81 Arts 370(1) and 371(1), DBA.

82 ibid arts 381(7)-(8). A class of creditors has adopted the plan when at least two-thirds of the total debt, in respect of which voting rights were exercised, have voted in favour of the plan. In the case of shareholders, a two-thirds majority of the subscribed capital is required.

83 arts 384-385, DBA.

84 ibid arts 383(1) and 384.

85 ibid art 373.

${ }^{86}$ The Law on the Stabilisation and Restructuring Framework for Enterprises (StaRUG) was introduced as part of a wider reform package, the Law for the Further Development of the Restructuring and Insolvency Laws (SanInsFoG), which came into force in Germany on January 1, 2021. Also in this context, the insolvency law contained in the German Insolvency Code (InsO) has been adjusted to act in concert with the new restructuring law.

${ }^{87}$ See s2, StaRUG.

88 ibid ss17 to 28 .

89 ibid ss49 to 59.

90 See ss217 ff, InsO. 
91 ibid ss88 to 91 .

92 ibid ss103 to 119.

93 A Review of the Corporate Insolvency Framework: A Consultation on Options for Reform (Insolvency Service, 2016) (August 19, 2021), available at: <https://assets.publishing.service.gov.uk/government/uploads/system/ uploads/attachment_data/file/525523/A_Review_of_the_Corporate_Insolvency_Framework.pdf >.

94 Administration (Restrictions on Disposal etc. to Connected Persons) Regulations 2021 (SI 2021/427) (August 19, 2021), available at: <https://www.legislation.gov.uk/uksi/2021/427/contents/made>.

95 Statement of Insolvency Practice 16.

96 See. for example, Giovanni Carmellino, 'Le droit français des entreprises en difficulté e i rapporti con la nuova normativa europea' [2015] Fallimento 1062; Massimo Cataldo, 'La soggezione dell'impresa in crisi al regime di allerta e composizione assistita' [2016] Fallimento 1022; Giacomo D'Attorre, 'Prime Riflessioni sulla Delega al Governo per la Riforma delle Discipline delle Crisi d'Impresa e dell'Insolvenza' [2017] Riv Soc 517, 521; Alessandro Pellegatta, 'La Riforma della Normativa sulle Crisi d'Impresa e dell'Insolvenza: Le Procedure di Allerta e Composizione Assistita' (March 8, 2017) Crisi d'Impresa e Fallimento 1, 2-8; Federico Pernazza, 'The Legal Transplant into Italian Law of the Procédure d'Alerte. Duties and Responsibilities of the Companies' Bodies' [2017] 3 Ital Law J 553; Antonio Mastrangelo, 'La prevenzione in Italia alla luce del decreto legislativo 12 gennaio 2019 n.14 (Codice della crisi d'impresa e della insolvenza)' Diritto.it (November 29, 2019), available at: <https://www.diritto.it/la-prevenzione-in-italia-alla-luce-del-decreto-legislativo-12gennaio-2019-n-14-codice-della-crisi-dimpresa-e-della-insolvenza/>.

${ }^{97}$ Eugenio Vaccari, 'The New 'Alert Procedure' in Italy: Regarder au-delà du modèle français?' [2021] 30 Int Insolv Rev 1.

98 See, among others: European Commission, Overcoming the stigma of business failure, for a second chance policy: Implementing the Lisbon Partnership for Growth and Jobs (November 27, 2009) COM(2007) 584 final (August 19, 2021), available at: <https://www.cedefop.europa.eu/sl/news-and-press/news/overcomingstigma-business-failure-second-chance-policy-implementing-lisbon $>$.

99 Aurelio Gurrea Martínez, 'Insolvency Law in Times of COVID-19' (9 June 2020) Ibero-American Institute for Law and Finance Working Paper 2/2020 (August 19, 2021), available at: <https://ssrn.com/abstract= 3562685> or <https://doi.org/10.2139/ssrn.3562685>.

${ }^{100}$ An example of this inconsistency is the availability for compensation and loan for businesses who have already entered formal insolvency proceeding. Where the compensation scheme for ordinary costs (rent etc.), cf bekendtgørelse $n r .574$ af 5. Maj 2020 om kompensation for faste omkostninger til virksomheder $i$ økonomisk krise som følge af COVID-19 is available to businesses which have already entered into a formal insolvency proceeding the interest free state loan is not.

${ }^{101}$ See also Emilie Ghio et al., 'The Limits and Logic of the EU Harmonisation Process in the Wake of COVID19' [2020] 80 Eurofenix (Summer) 22.

102 In an international context see also the Dutch Borgstelling MKB, Garantie Ondernemersfinanciering and Klein Krediet Corona and the Danish state-guaranteed loaning schemes via The Danish Growth Fund where the Danish State provided a guarantee of up to 70\% for new bank loans, cf BEK nr 256 af March 23, 2020 and BEK nr 981 af June 24, 2020. The loans are limited to the amount of expected loss in earnings.

103 The Italian furlough scheme is known as the cassa integrazione. Following the pandemic, payments from businesses to the fund have been waived while the number of beneficiaries has been expanded (Decree-Law 18/2020).

104 Coronavirus Job Retention Scheme 2020, effective with amendments until September 30, 2021.

105 BEK nr 461 af March 18, 2021. (August 19, 2021), See further: <https://virksomhedsguiden.dk/erhver vsfremme/content/temaer/coronavirus_og_din_virksomhed/ydelser/loenkompensation/8a8e7687-ab06-4524aea6-dea26d6e95da/>.

106 Tijdelijke Noodmaatregel Overbrugging voor Werkgelegenheid. See further: 'Coronavirus og din virksomhed' (August 19, 2021), available at: <https://www.rijksoverheid.nl/onderwerpen/coronavirus-financiele-rege lingen/overzicht-financiele-regelingen/now $>$. 
107 The requirements to make use of the German furlough scheme, which was already in place as a measure for social stabilisation, were further relaxed with the Verordnung über Erleichterungen der Kurzarbeit (Kurzarbeitergeldverordnung/KugV) in March 2020 as a reaction the COVID-19 pandemic.

${ }^{108}$ See Décret no2020-325 du 25 mars 2020 relatif à l'activité partielle; Ordonnance no2020-341 du 27 mars 2020 portant adaptation des règles relatives aux difficultés des entreprises et des exploitations agricoles à l'urgence sanitaire et modifiant certaines dispositions de procédure pénale; Ordonnance no2020-770 du 24 juin 2020 relative à l'adaptation du taux horaire de l'allocation d'activité partielle; Décret no2020-810 du 29 juin 2020 portant modulation temporaire du taux horaire de l'allocation d'activité partielle.

${ }^{109}$ Miles Johnson and Silvia Sciorilli Borrelli, 'Can Renationalisation get Alitalia Off the Ground?' (Financial Times, 23 June 2020), available at: <https://www.ft.com/content/f4eceeee-6cb7-4908-85a953d1423856e7>.

${ }^{110}$ State Aid: Commission Approves French Plans to Provide 7 Billion in Urgent Liquidity Support to Air France (European Commission 4 May 2020), available at: <https://ec.europa.eu/commission/presscorner/detail/en/ IP_20_796>; State Aid: Commission Approves Dutch Plans to Provide 3,4 Billion in Urgent Liquidity Support to KLM (European Commission 13 July 2020) (August 19, 2021), available at: <https://ec.europa.eu/ commission/presscorner/detail/en/IP_20_1333>.

111 This is also partly due to the fact that a majority of Member States have yet to implement the PRD: "Tracker on the Implementation of the EU Directive on Restructuring and Insolvency" (INSOL Europe 15 March 2021). The tracker is <https://www.insol-europe.org/tracker-eu-directive-on-restructuring-and-insolvency $>$. On the face of it, Germany, the Netherlands and the United Kingdom have implemented the PRD or adopted legislation inspired by the Directive in 2020, but it comes with some caveats when considering it as a COVID19 response. The adoption of the UK Part 26A Restructuring Plan in the CIGA and the Dutch WHOA were the result of ongoing legislative initiatives for some years before the COVID-19 pandemic emerged. The German implementation of the Directive, the StaRUG, was not part of the initial COVID-19 response. Instead, the StaRUG entered into force only on January 1, 2021 and then only partially. The provisions regarding a private StaRUG are in force, for the public StaRUG this will have to wait for July 2022. Instead, from the start, most efforts have been directed toward amending tried and tested insolvency mechanisms or adopting noninsolvency measures.

${ }^{112}$ Reinhard Bork, 'Preventive Restructuring Frameworks: A ‘Comedy of Errors' or 'All's Well That Ends Well?' [2017] 14 Int Corp Rescue 417, 425.

${ }^{113}$ For example, the European Commission in its Inception Impact Assessment, "Initiative on Insolvency", DGJUST (A1), 2016/JUST/025 - INSOLVENCY II of March 3, 2016 stated that (emphasis added): "The scope of the harmonisation of insolvency laws could capture [...]" (6), as well as "There is a greater need for convergence in insolvency law and restructuring proceedings across Member State." (2). It is also stated in the PRD Proposal 2016 that (emphasis added): "Increased convergence of insolvency and restructuring procedures would facilitate greater legal certainty." (2), as well as "[T]he focus of this proposal is on addressing the most important problems that could be feasibly addressed by harmonisation" (6).

${ }^{114}$ European Commission, Inception Impact Assessment, "Enhancing the convergence of insolvency laws" (DG JUST A1, November 11, 2020).

${ }^{115}$ We also came across "approximation" three times in the Inception Impact Assessment. Although intertwined with our discussion and thus, our recommendation for a more accurate use of language by EU institutions applies equally, we leave this construct out of the scope of this paper.

${ }^{116}$ Nikolaj Fischer, "Rechts-Harmonisierung” - Schlagwort order Rechtsprinzip? - Kritische Anmerkungen zum Prozess der "Rechts-Angleichung"' [2003] 10 Verbraucher und Recht 374.

${ }^{117}$ Definition of 'harmonisation' in the Cambridge dictionary.

118 Definition of 'convergence' in the Cambridge dictionary. A similar definition is provided in the Collins dictionary: "The convergence of different ideas, groups, or societies is the process by which they ... become more similar."

${ }^{119}$ Definition of 'convergence' in the Merriam-Webster dictionary. 
${ }^{120}$ Ray Warner, 'Reimagining Rescue: The View from the United States', in Rebecca Parry and Paul Omar (eds), Reimagining Rescue (INSOL Europe 2016) 175, 177.

${ }^{121}$ See the definition of the word "recast" in the Cambridge Dictionary.

${ }^{122}$ Horst Eidenmüller, 'A New Framework for Business Restructuring in Europe: The EU Commission's Proposals for a Reform of the European Insolvency Regulation and Beyond' [2013] 20 Maastricht J $133,150$.

123 Gerard McCormack, 'Reforming the European Insolvency Regulation: A Legal and Policy Perspective' [2014] $10 \mathrm{~J}$ Priv Int Law 41, 67.

124 ibid.

125 PRD Proposal 2016, 7.

126 See also Andreas Piekenbrock, 'Das ES UG -fit für Europa?' NZI 22/2012, 906ff, who, as early as 2012, had already observed similar approaches regarding rescue proceedings in a comparative study of Austria, Belgium, England, France, Germany and Italy.

127 See. for example Case C-191/10, Rastelli Davide e C. Snc v Jean-Charles Hidoux, ECLI:EU:C:2011:838; Case C396/09, Interedil Srl v Fallimento Interedil Srl, ECLI:EU:C:2011:671; Case C-1/04, Susanne Staubitz-Schreiber, ECLI:EU:C:2006:39; Case c-341/04, Eurofood IFSC Ltd, ECL:EU:C:2006:281.

${ }^{128}$ Re Collins \& Aikman Europe SA and other Companies [2006] EWHC 1343 (Ch).

129 David Nelken, 'Legal Transplants and Beyond: Of Disciplines and Metaphors', in Andrew Harding and Esin Örücü (eds), Comparative Law in the 21st Century (Kluwer Law International 2002), 19, 26.

130 European Commission Impact Assessment Accompanying the document Proposal COM(2016) 723 final 2016/0359 (COD) for a Directive of the European Parliament and of the Council on preventive restructuring frameworks, second chance and measures to increase the efficiency of restructuring, insolvency and discharge procedures and amending Directive 2012/30/EU [2016] Document 52016PC0723, 55: "For the key sub-options on debtor-in-possession, stay on enforcement, cram-down, new finance the inspiration came originally from the work of INSOL Europe at the time of the 2014 Recommendation ... from best practices in this area, ... from the review of the implementation in the Member States" (emphasis added).

131 See Warner (ibid 120), 180.

132 Horst Eidenmüller, 'Contracting for a European Insolvency Regime' [2017] 18 Eur Bus Org Law Rev 273, 278 (emphasis added).

133 ibid.

${ }^{134}$ See. for example, Stephan Madaus, 'The EU Recommendation on Business Rescue - Only Another Statement or a Cause of Legislative Action Across Europe?' [2014] 27 Insolv Intell 6; Horst Eidenmüller and Kristin van Zwieten, 'Restructuring the European Business Enterprise: The EU Commission Recommendation on a New Approach to Business Failure and Insolvency' (2015) European Corporate Governance Institute Law Working Paper 301/2015, 11 (August 19, 2021), available at: <https://ssrn.com/abstract=2662213>.

135 Eidenmüller (ibid 132), 290.

136 PRD Proposal 2016, 6 (emphasis added).

137 ibid, 2.

138 See the European Commission's own statement in $\operatorname{COM}(2020) 112$ final, 2: "The COVID-19 pandemic is a major shock to the [...] European economy."

139 Eidenmüller (ibid 132), 288.

140 Bork (ibid 112), 419.

141 ibid.

142 Nicolaes Tollenaar, 'The European Commission's Proposal for a Directive on Preventive Restructuring Proceedings' [2017] 5 Insolv Intell 65, 71.

143 PRD Proposal 2016, 7.

144 Bork (ibid 112), 425. 
${ }^{145}$ Note also other stakeholders' initiatives and projects looking at furthering the harmonisation of selected areas of insolvency law, for example, "Harmonisation of insolvency law and the European Business Code" by Reinhard Bork and Michael Veder.

How to cite this article: Ghio, E., Boon, G.-J., Ehmke, D., Gant, J., Langkjaer, L., \& Vaccari, E. (2021). Harmonising insolvency law in the EU: New thoughts on old ideas in the wake of the COVID-19 pandemic. International Insolvency Review, 1-33. https://doi. org/10.1002/iir.1432 